\title{
Piotr Kołodko
}

\section{Omnis autem actio vacare debet temeritate et neglegentia*. Kilka uwag na marginesie pracy Dominiki Mróz, Prawo rzymskie. Testy dla studentów, Warszawa 2009}

Keywords: Roman law, handbook, quiz

\section{Summary}

The main purpose of the text was to raise a few objections about the handbook of D. Mróz. It has been underlined that the preponderance of mistakes disqualifies this book as a recommended one for the students. A student who refuses to repeat some parts of Roman law with this publication will not be as much disappointed as that who followed the view of Roman law presented by the author.

D. Mróz should have had to put more emphasis on preparing her questions and cases in a more meticulous way. It is unthinkable that a student has to decide which answer is correct when more than one seems to be proper. Furthermore, the variety of questions and cases referring to property law and the law of obligation seems to be insufficient. It is in vain to look for a rule superficies solo cedit or nemo plus iuris in alium transferre potest, quam ipse haberet. An inquisitive student will be disappointed by a quantity of questions concerning to e.g. obligations ex delicto.

This publication requires a thorough amendments, as well a review by a competent Romanist. When the underlined mistakes are eliminated by the author, the book will be acceptable.

Oferta wydawnicza w postaci książek, czy też różnych zbiorów sprawdzających wiedzę z zakresu prawa rzymskiego, jest niezwykle bogata ${ }^{1}$. Dzięki temu student nie tylko ma możliwość sięgnięcia po podręcznik (w celu pogłębienia i usystematyzowania wiedzy), ale przede wszystkim może skorzystać z innych pomocy dydaktycznych, które pozwolą mu utrwalić i powtórzyć zdobyte informacje. Trzeba jednak pamiętać, że przygotowanie rzetelnego repetytorium czy też solidnego zestawu pytań testowych powinno być poprzedzone dłuższym doświadczeniem dydaktycznym, które pozwoliłoby dokonać takiego wyboru materiału, który sprawia studentom względnie największe trudności. Tak skonstruowana pomoc dydaktyczna dawałaby studentowi podstawę do weryfikacji

* Cic., de Off. 1, 29, 101.

1 Zob. T. Palmirski, R. Pabis, J. Reszczyński, Prawo rzymskie. Repetytorium, Kraków 1999; A. Kacprzak, J. Krzynówek, Prawo rzymskie. Pytania egzaminacyjne, kazusy, tablice², Warszawa 2008; Prawo rzymskie. Repetytorium, red. P. Święcicka-Wystrychowska, Kraków 2003; J. Misztal-Konecka, M. Wójcik, Rzymskie prawo prywatne. Kazusy i ćwiczenia, Warszawa 2007. 
jego wiedzy. Warto zatem jest przyjrzeć się, czy takim kryterium, dokonując wyboru materii pytań, kierowała się Dominika Mróz.

Cel, jakiemu służyć ma praca Autorki, to nie tylko powtórka materiału kursowego, ale także ,...pomoc dydaktyczna w przyswojeniu przez studenta rudymentarnych pojęć prawniczych oraz zasad funkcjonowania podstawowych instytucji prawa cywilnego i procesowego...”, zob. Wprowadzenie. Poniższe uwagi mają na celu weryfikację założenia Autorki.

Praca D. Mróz ${ }^{2}$ to zestaw 900 pytań zamkniętych wraz z kluczem odpowiedzi, obejmujących wiedzę z całości rzymskiego prawa prywatnego (za Autorką: źródła prawa rzymskiego i jego recepcja, prawo osobowe, czynności prawne, prawo rzeczowe, zobowiązania, prawo spadkowe, prawo rodzinne i wreszcie prawo procesowe). Już taki układ materii wskazuje, że nawiązuje ona do usus modernus pandectarum. Należałoby się jednak zastanowić, czy z punktu widzenia dydaktyki przedmiotu zasadne jest umieszczenie prawa rodzinnego praktycznie na samym końcu pytań testowych (rozdz. VII). Wydaje się, że najbardziej przejrzysty układ odzwierciedlałby podział materii na personae-resactiones i w przystępny, i logiczny sposób dawałby studentowi przejście do kolejnej „gałęzi" prawa. Jest to o tyle uzasadnione, że chociażby poruszana problematyka podmiotowości prawnej oddziałuje na prawo rodzinne.

Zupełnie odrębną kwestią jest pojmowanie materii prawa rodzinnego, bowiem pytania odnoszące się do niej oscylują w przeważającej większości wokół małżeństwa rzymskiego i kwestii z nim związanych (zaręczyny, posag, darowizny małżeńskie, rozwód). Wyjątkowo mało jest pytań poświęconych instytucjom adoptio, adrogatio, sytuacji prawnej osób pod partia potestas (w szczególności brak pytań dotyczących peculium castrense, quasi castrense, adventicium). Tym samym nasuwa się pytanie - czy nazwa rozdziału VII - Prawo rodzinne - jest adekwatna do jego zawartości. Mając na uwadze podniesione kwestie, zasadne wydaje się nazwanie tego rozdziału Małżeństwo rzymskie, co prowadziłoby do wyeliminowania sformułowanej wątpliwości. W żaden jednak sposób nie uchroniłoby to jednak Autorki przed zarzutem pominięcia wskazanych kwestii, bowiem niewiele jest ich także w rozdziale II (Prawo osobowe), gdzie potencjalnie można by ich poszukiwać.

Podstawową uwagą, jaką należy podnieść pod adresem przedmiotowego wyboru pytań, jest ich nieprecyzyjne sformułowanie ${ }^{3}$. Widoczne jest to praktycznie w każdym

2 Autorka jest doktorantką w Katedrze Prawa Cywilnego Uniwersytetu Jagiellońskiego - zob. http:// www.law.uj.edu.pl/ kprcyw/index.php/doktoranci z dnia 20 lutego 2011 r. Jest także współredaktorem następujących publikacji (wraz z M. Araszkiewiczem) - Prawo rzeczowe. Repetytorium, Warszawa 2010 oraz (wraz z B. Baligą i R. Piaseckim) Aplikacja 2010. Prawo cywilne. Część I, Warszawa 2010 - por. http://www.eofucyna.com.pl z dnia 20 lutego $2011 \mathrm{r}$.

3 Dobrą ilustracją tej nagannej praktyki mogą być pytania z zakresu prawa spadkowego. Otóż w pytaniu 655, mówi się o „....sporządzeniu testamentu w formie nuncupatio.... Warto wskazać, że takiej formy testamentu prawo rzymskie nie przewidywało, a sama nuncupatio była ustnym oświadczeniem składanym przy zawieraniu czynności formalnych (np. najbliższa prawu spadkowemu mancipatio familiae). O doniosłości nuncupatio może świadczyć fakt, że wspomina o niej już lex duodecim 
rozdziale, poświęconym sprawdzeniu wiedzy z danej gałęzi prawa rzymskiego. Wskutek tego zdarza się, że można trafić na pytanie, na które trudno wskazać prawidłową odpowiedź, nawet gdy jest ona podana w wariancie do wyboru, bowiem jego konstrukcja na to nie pozwala. Jako przykład może posłużyć pytanie 379, gdzie Autorka zdaje się sprawdzać wiedzę z instytucji zasiedzenia (usucapio) ${ }^{4}$. Jednakże jego brzmienie: „...w Ustawie XII tablic do nabycia prawa własności do ruchomości wymagany był okres..." pomija najistotniejszą kwestię, tzn. nie wskazuje sposobu nabycia tejże własności. Zasadne było dodanie, że chodzi tu o nabycie prawa własności do ruchomości w drodze zasiedzenia (podr. P.K.), bowiem taka redakcja pytania uprawnia do wyboru poprawnie wskazanej w kluczu odpowiedzi b) - por. s. 242. Takich nieprecyzyjnych pytań jest zdecydowanie więcej.

Druga istotna kwestia, którą należy podnieść, to brak jednoznacznego wskazania, czy poszczególne pytania mają jedną bądź więcej poprawnych odpowiedzi do wyboru. Choć lektura większości z nich oraz klucz odpowiedzi dają pośrednią wskazówkę (jedna poprawna odpowiedź), to pewne wątpliwości nasuwają się przy lekturze niektórych z nich. Ryzykowne jest bowiem twierdzenie w pytaniu 420, że zobowiązaniem dwustronnym nierównoczesnym ( $\mathrm{w}$ nomenklaturze używanej w pytaniu brzmi to: „...umowa kreująca zobowiązanie dwustronne niedoskonałe...”) jest wyłącznie przechowanie (depositum) - por. s. 246, skoro w wyborze odpowiedzi znajduje się jeszcze zlecenie (mandatum). Charakter prawny mandatum jako obligatio bilateralis inaequalis nie budzi żadnych wątpliwości i jest jednoznacznie poświadczony źródłowo ${ }^{5}$. Jest o tym

tabularum - Tab. VI, 1. Również analiza pytania 666 rodzi konsternację w zakresie jego precyzji. Autorka wskazała w nim, że Rzymianka sui iuris od okresu prawa klasycznego mogła sporządzić testament. W istocie, tak byłoby, gdyby korzystała z przywileju ius trium liberorum, lecz tej wzmianki zabrakło. Poza tym nie można ulec pokusie, że D. Mróz, konstruując pytanie w takim kształcie, zdaje się stać na zupełnie błędnym stanowisku niemożliwości sporządzenia testamentu przez kobietę sui iuris przed okresem klasycznym. Szerzej o testamentach kobiet zob. J. Zabłocki, Appunti sul «testamentum mulieris», BIDR 94-95, 1991-1992, s. 157-179. Ponadto trzeba pamiętać o instytucji tutela mulierum, wygasającej właśnie w okresie prawa klasycznego, której podlegały dojrzałe Rzymianki sui iuris. Przy pomocy tutora (w postaci interpositio auctoritatis tutoris) kobieta sui iuris mogła sporządzić testament zdecydowanie wcześniej niż w okresie prawa klasycznego. Natomiast rozważając pytania 696 oraz 697, D. Mróz zdaje się wymagać od studenta „zgadnięcia”, o jaki reżim dziedziczenia pyta. Oba pytania odwołują się do wskazania dziedziców pierwszej i drugiej klasy, lecz nie precyzują, czy dotyczy to klas dziedziców wedle lex duodecim tabularum, czy może edyktu pretora bądź nowel Justyniana. Chociaż lektura odpowiedzi daje jednoznaczną wskazówkę o reżim dziedziczenia (tj. według ustawy XII Tablic), to bardziej wartościowe, z punktu widzenia chociażby metodologii układania pytań, byłoby umieszczenie tej informacji w samej jego treści. Wydaje się, że gdyby bardziej rzetelnie sformułowano przytoczone pytania, uniknęłoby się wskazanych pod ich adresem zastrzeżeń.

4 Uwagi uczynione na tle tego pytania można - odpowiednio - odnieść do poprzedzającego je (tj. 378), dotyczącego nabycia prawa własności do rzeczy nieruchomej.

5 Zob. D. 17, 1 - Mandati vel contra. Taki tytuł tej księgi Digesta Iustiniani wskazuje, że w przypadku zlecenia istniały dwie przeciwstawne sobie skargi - mandans korzystał z actio (mandati) directa, a mandatariusz z actio (mandati) contraria. Warto podkreślić, że istnienie tego zespołu skarg jest charakterystyczne dla zobowiązań dwustronnych nierównoczesnych - zob. np. D. 16, 3 - Depositi vel contra; D. 13, 6 - Commodati vel contra; D. 13, 7 - De pigneraticia actione vel contra. 
mowa praktycznie w każdym podręczniku do prawa rzymskiego, a nierównoczesny charakter zlecenia wyróżnia je na tle pozostałych kontraktów konsensualnych ${ }^{6}$. Tym samym dano studentowi możliwość wyboru więcej niż jedna poprawna odpowiedź, zaś w kluczu wskazano tylko jeden prawidłowy wariant.

Podobną uwagę można skierować pod adresem pytania 477, dotyczącego stopnia odpowiedzialności komodatariusza. Wydaje się bowiem, że warianty odpowiedzi są niepoprawnie zredagowanie pod względem logicznym. Zdaniem Autorki dłużnik odpowiadał „...także za strzeżenie rzeczy (custodia), która została mu użyczona...” (por. s. 252). Zdziwienie budzi jednak nieuwzględnienie jako poprawnej odpowiedzi c), stanowiącej o odpowiedzialności za omnis culpa. Nie ulega bowiem wątpliwości, że komodatariusz taką odpowiedzialność ponosił ${ }^{7}$, co wiązało się z faktem używania przez niego rzeczy, a zatem czerpania korzyści z kontraktu. Po raz kolejny podano więcej niż jedną poprawną odpowiedź, lecz struktura całego zbioru pytań umożliwia dokonanie wyboru tylko jednego wariantu, nawet gdy inne są prawidłowe.

Przechodząc do szczegółowego omówienia wybranych pytań testowych, nie sposób nie wskazać błędów, jakich nie ustrzeżono się podczas ich przygotowywania. W pytaniu 7 nastąpiło zawężenie źródeł ius civile 8 jedynie do ustaw i zwyczaju. Gdyby nawet przyjąć, że pytanie dotyczy tylko okresu prawa archaicznego, to nie można nie wspomnieć o plebiscytach (plebisicta) jako źródle prawa, abstrahując już od sporu toczonego w romanistyce odnośnie daty zrównania leges z plebiscita ${ }^{9}$. Wydaje się, że tak skonstruowane pytanie daje studentowi mylne wyobrażenie o źródłach ius civile i chcąc utrzymać jego kształt, warto by w jego treści dodać sformułowanie „między innymi”.

Zupełne zdumienie budzi już odpowiedź na pytanie 11, gdzie czytelnik (lege: student) dowiaduje się, że autorem Noctes Atticae ${ }^{10}$ jest - zdaniem Autorki (zob. odp. na

6 R. Taubenschlag, Rzymskie prawo prywatne, Warszawa 1955, s. 215-217; W. Osuchowski, Zarys rzymskiego prawa prywatnego ${ }^{4}$, Warszawa 1971, s. 431-433; B. Biondi, Istituzioni di diritto romano ${ }^{4}$, Milano 1972, s. 510-514; W. Rozwadowski, Prawo rzymskie. Zarys wykładu wraz z wyborem źródeł², Poznań 1992, s. 181-182; K. Kolańczyk, Prawo rzymskie ${ }^{5}$, Warszawa 2000, s. 404-407; A. Guarino, Diritto romano privato $^{12}$, Napoli 2001, s. 928-935; G. Nicosia, Nuovi profili istituzionali essenziali di diritto romano, Catania 2001, s. 262-264; W. Litewski, Rzymskie prawo prywatne ${ }^{5}$, Warszawa 2003 , s. 295-296; V. Arangio-Ruiz, Istituzioni di diritto romano ${ }^{14}$, Napoli 2006, s. 351-353; A. Dębiński, Rzymskie prawo prywatne. Kompendium ${ }^{4}$, Warszawa 2008, s. 301-303; M. Kuryłowicz, A. Wiliński, Rzymskie prawo prywatne. Zarys wykładu4, Warszawa 2008, s. 258-259; W. Wołodkiewcz, M. Zabłocka, Prawo rzymskie. Instytucje $e^{5}$, Warszawa 2009, s. 236-237.

7 D. 50, 17, 23 (Ulpianus libro vicensimo nono ad Sabinum): Contractus quidam dolum malum dumtaxat recipiunt, quidam et dolum et culpam. (...) dolum et culpam mandatum, commodatum, venditum, pignori acceptum, locatum, item dotis datio, tutelae, negotia gesta: in his quidem et diligentiam.

8 Por. G. 1, 2: Constant autem iura populi Romani ex legibus, plebiscitis, senatus consultis, constitutionibus principum, edictis eorum, qui ius edicendi habent, responsis prudentium. Wymienione źródła prawa odnoszą się do wszystkich okresów rozwoju prawa rzymskiego, co jest odzwierciedleniem dydaktycznego charakteru dzieła Gaiusa.

9 W tej kwestii zob. J. Zabłocki, 'Leges de plebiscitis', PK 35, 1992, nr 1-2, s. 237-246.

10 Szerzej o Gelliusie zob. J. Zabłocki, Rozważania o procesie rzymskim w Noctes Atticae Aulusa Gelliusa, Warszawa 1999; The worlds of Aulus Gellius, ed. L. Holford-Strevens, A. D. Vardi, New York 2004. 
s. 210) - Sextus Pompeius Festus ${ }^{11}$ (sic!). Wskazany błąd można by traktować jako „oczywistą omyłkę pisarską", gdyby nie jasne twierdzenie zawarte w kluczu odpowiedzi, niepozostawiające wątpliwości co do błędnego autorstwa Noctes Atticae.

Również niefortunnie zostało sformułowane pytanie 24, gdzie twierdzi się, że adiuvandi iuris civilis gratia polegała na „...wyjaśnianiu przepisów prawa cywilnego..." (również prawa karnego w odp. d). Należy wskazać, że kompetencja pretora, do jakiej nawiązuje pytanie, była jasno określona przez Papiniana ${ }^{12}$. Kluczowe jest jednak poprawne rozumienie czasownika adiuvare. Jego leksykalne znaczenie, w swoim podstawowym brzmieniu, wskazuje, że należy interpretować go jako „wspierać”, „wspomagać”13. Wydaje się więc, że adiuvandi iuris civils gratia to uprawnienie polegające na „wspomaganiu prawa cywilnego”. Zdecydowana większość romanistów stoi na takim stanowisku ${ }^{14}$.

Elementem, który wyjątkowo razi w przedmiotowym wyborze testów, jest kwestia używanej przez Autorkę nomenklatury ${ }^{15}$. Widać to chociażby w pytaniu 37, gdzie sugeruje się, że decreta to „...cesarskie orzeczenia sądowe...” ${ }^{16}$. Trafniej było wskazać, że cho-

11 Festus jest autorem dzieła De verborum significatu; por. ostatnio w tej kwestii: P. Pieroni, Marcus Verrius Flaccus' de Significatu verborum in den Auszügen von Sextus Pompeius Festus und Paulus Diaconus. Einleitung und Teilkommentar (154,19 - 186,29 Lindsay), Frankfurt am Main 2004.

12 Zob. D. 1, 1, 7, 1 (Papinianus libro secundo definitionum): Ius praetorium est, quod praetores introduxerunt adiuvandi vel supplendi vel corrigendi iuris civilis gratia propter utilitatem publicam. quod et honorarium dicitur ad honorem praetorum sic nominatum.

13 J. Sondel, Słownik łacińsko-polski dla prawników i historyków, Kraków 1997, s.v. adiuvo - 1, s. 27; Słownik łacińsko-polski, red. M. Plezia, Warszawa 1998, s.v. adiuvo, -are, s. 67.

14 Por. B. Biondi, op. cit., s. 19-20; G. Nicosia, op. cit., s. 27; zob. także: R. Taubenschlag, op. cit., s. 29; W. Rozwadowski, op. cit., s. 233; K. Kolańczyk, op. cit., s. 62; A. Dębiński, op. cit., s. 33; M. Kuryłowicz, A. Wiliński, op. cit., s. 37; W. Wołodkiewicz, M. Zabłocka, op. cit., s. 53. Jako zwolennika interpretacji adiuvare w znaczeniu zaprezentowanym przez Autorkę można wskazać W. Osuchowskiego (op. cit., s. 65).

15 W pytaniu 159 Autorka pytając o ustawę zakazującą intercessio kobietom, wśród zaproponowanych odpowiedzi podaje jedną lex, dwa razy senatus consultum oraz jedną konstytucję cesarską. Wydaje się, że tak sformułowane pytanie jest nieprecyzyjne, bowiem dla Rzymian lex est quod populus iubet atque constituit (G. 1, 3; w toku rozwoju prawa rzymskiego także i plebiscita zrównano z leges). O ile do tak sformułowanego pytania można by jeszcze włączyć konstytucje cesarskie (por. G. 1, 5), to sprawa postrzegania senatus consultum jako ustawy już nie była tak oczywista - G. 1, 4: Senatus consultum est, quod senatus iubet atque constituit; idque legis vicem optinet, quamvis fuerit quaesitum. Mając na uwadze te kwestie, należy stwierdzić, że niezbyt rzetelnie, pod względem terminologicznym, sformułowano propozycje odpowiedzi. Większą konsternację budzi nazwanie środków ochrony posesoryjnej mianem powództw (zob. pytanie 388). O możliwości wniesienia actio (odpowiadającej znaczeniowo powództwu) można mówić w przypadku, gdy doszło do naruszenia interesu jednej ze stron danej czynności prawnej (np. niewykonanie lub nienależyte wykonanie zobowiązania), a polubowne rozwiązanie sporu jest wykluczone i strony poddają się decyzji sędziego. Natomiast posiadanie, będące stanem faktycznym, podlegało ochronie interdyktalnej, przyznawanej przez pretora, a realizowanej w trybie postępowania pozaprocesowego. Stąd też mówienie w kontekście posiadania o ochronie w drodze powództwa jest niepoprawne. Wydaje się, że w tym przypadku Autorka przeniosła na grunt prawa rzymskiego współczesną siatkę pojęciową cywilistyki.

16 Taką terminologią posługują się także autorzy najnowszej publikacji dotyczącej rzymskiego prawa publicznego - zob. A. Dębiński, J. Misztal-Konecka, M. Wójcik, Prawo rzymskie publiczne, Warszawa 2010 , s. 82 . 
dzi tu raczej o rozstrzygnięcia ${ }^{17}$ cesarskie, bowiem cesarzowi przysługiwało imperium proconsulare maius, dające podstawę do wydawania edicta principium ${ }^{18}$. Poza tym wydaje się, że termin „orzeczenia” jest bliższy współczesnym systemom prawnym. Z drugiej jednak strony nie można pominąć milczeniem tych autorów, którzy taką terminologią się posługują ${ }^{19}$. Stąd też wskazane uchybienie nie jest aż tak znaczące, jak inne, wskazane w dalszej części.

Nie można także nie wspomnieć o wadliwie skonstruowanym pytaniu 410, w którym zaproponowano sprawdzenie wiedzy dotyczącej interdictum Salvianum. Z punktu widzenia terminologii, spośród czterech wariantów odpowiedzi, żaden nie jest poprawny. Nie można bowiem się zgodzić, że środek ochrony pozaprocesowej, jakim bezsprzecznie jest interdykt Salwiański, można nazwać „prawem” czy „skargą”. Natomiast w kwestii merytorycznej zupełnie błędne jest pojmowanie interdictum Salvianum jako „...prawa zastawu na inwentarzu dzierżawcy na zabezpieczenie spłaty należności właściciela $\mathrm{z}$ tytułu czynszu..." (odpowiedź wskazana w kluczu jako prawidłowa - s. 245). Celem interdictum Salvianum było umożliwienie wejścia w posiadanie wydzierżawiającemu (wydaje się, że lepiej było użyć tego terminu w treści pytania, zamiast wskazanego „właściciela”; z pewnością byłoby ono bardziej klarowne) zastawionego przez dzierżawcę inwentarza, co umożliwiało rozpoczęcie realizacji uprawnień zastawnika względem przedmiotu zastawu.

Nie do przyjęcia jest też sugestia, że zdolność prawna była pełna lub ograniczona (por. pytanie 57). W prawie rzymskim podmiotem prawa był tylko ten, kto łącznie spełniał następujące przesłanki - był wolny (status libertatis), posiadał obywatelstwo rzymskie (status civitatis) oraz był osobą sui iuris (status familiae) ${ }^{20}$. Jeszcze większy zamęt wprowadza się, podając w kluczu odpowiedzi (s. 213), że „...na ograniczenie zdolności prawnej miały wpływ m.in.: stan obywatelstwa, stanowisko w rodzinie, cześć oraz płeć.... O ile można wskazać romanistów uznających wpływ infamii na podmiotowość

17 Por. K. Kolańczyk, op. cit., s. 43; W. Wołodkiewicz, M. Zabłocka, op. cit., s. 57 Można też było pokusić się o określenie decreta jako wyroków wydawanych przez cesarza - zob. B. Biondi, op. cit., s. 27; W. Kunkel, Linee di storia giuridica romana (traduzione T. e B. Spagnuolo Vigorita), Napoli 1973, s. 177; W. Kunkel, M. Schermaier, Römische Rechtsgeschichte ${ }^{13}$, Köln - Weimar - Wien 2001, s. 171; W. Rozwadowski, op. cit., s. 41; A. Guarino, op. cit., s. 105; G. Nicosia, op. cit., s. 32; V. Arangio-Ruiz, Storia del diritto romano ${ }^{12}$, Napoli 2006, s. 246; M. Kuryłowicz, A. Wiliński, op. cit., s. 41.

18 A. Guarino, op. cit., s. 104

19 W polskiej romanistyce można wskazać autorów, którzy określają decreta jako orzeczenia cesarskie - zob. R. Taubenschlag, op. cit., s. 39; W. Osuchowski, op. cit., s. 86; W. Litewski, op. cit., s. 70; A. Dębiński, op. cit., s. 72.

20 Nie można podzielić poglądu Autorki, że zasada (paremia) nasciturus pro iam nato habetur quotiens de commodis eius agitur (pytanie 81) została sformułowana w okresie panowania Justyniana. Trzeba nadmienić, że w żadnym miejscu kodyfikacji Justyniana, a także w nowelach, nie ma mowy o tej zasadzie. Choć podstawę do jej sformułowania stanowiły wypowiedzi jurystów zawarte w Digesta Iustinani (zob. np. D. 1, 5, 7; D. 50, 16, 213), to ostateczny kształt został nadany w średniowieczu por. A. Dębiński, op. cit., s. 136; P. Niczyporuk, Prywatnoprawna ochrona dziecka poczętego w prawie rzymskim, Białystok 2009, s. 29, wraz z odesłaniem do literatury. 
prawną $^{21}$, to przesłanka płci ${ }^{22}$ jest skorelowana raczej ze zdolnością do czynności prawnych. Wydaje się więc, że Autorka dokonała wymieszania przesłanek nabycia zdolności prawnej z tymi, które odnoszą się do zdolności do czynności prawnych. Trzeba podkreślić, że konsekwencja tego błędu ujawnia się także w pytaniu 66, odnoszącym się do utraty zdolności prawnej. Zdaniem Autorki, capitis deminutio „...oznacza całkowitą lub częściową utratę zdolności prawnej.... Konstrukcja tej odpowiedzi zdaje się dowodzić, że utrata jednego ze status pozwala utrzymać zdolność prawną, ale ograniczoną, czyli chyba taką, która mimo wszystko pozwala na uczestnictwo w obrocie prawnym. $\mathrm{W}$ innym wypadku zbędne byłoby wskazywanie na ograniczoną zdolność prawną. Trzeba jednak podkreślić, że sugerowane założenie jest błędne, bowiem utrata status libertatis, civitatis lub status familiae automatycznie pozbawiały podmiot zdolności prawnej. Tym samym wykluczone było posiadanie zdolności prawnej ograniczonej, gdyż prawo rzymskie nie znało takiej konstrukcji. W konsekwencji Quintus, syn obywatela rzymskiego, będący pod patria potestas (a zatem osoba alieni iuris), nie mógł w świetle prawa rzymskiego zostać np. wierzycielem, właścicielem, spadkobiercą, etc. Choć ewidentnie był obywatelem Rzymu i osobą wolną, to mimo wszystko, zgodnie z ius civile, nie był traktowany jako podmiot prawa. Czy zatem miał sugerowaną przez Autorkę ograniczoną zdolność prawną? Wydaje się, że nie, bowiem Quintus był w ogóle jej pozbawiony ${ }^{23}$, o czym przesądzał jego status familiae.

W konstrukcji pytania 116 sugeruje się, że w prawie rzymskim niewolnik nie mógł być przedmiotem hipoteki, gdyż zaliczano go do res mobiles (odp. na s. 220). Należy podkreślić, że na gruncie prawa rzymskiego hipoteka (zwana też pignus conventum) była jedną z możliwych (obok pignus i fiducia) form zastawu. Nie była zatem skorelowana z rzeczami nieruchomymi, jak to jest widoczne we współczesnej regulacji ustawowej ${ }^{24}$. Stąd też w prawie rzymskim przedmiotem hipoteki (pignus conventum) mogły być zarówno res moblies oraz immobiles ${ }^{25}$. Sugerowanie studentowi, że rzymska hipoteka nie

21 Wśród polskich romanistów za wpływem czci na zdolność prawną opowiedzieli się m.in.: R. Taubenschlag, op. cit., s. 117-118; W. Osuchowski, op. cit., s. 243-244; K. Kolańczyk, op. cit., s. 182 W. Litewski, op. cit., s. 141-142; A. Dębiński, op. cit., s. 152-154; M. Kuryłowicz, A. Wiliński, op. cit., s. 97-98.

22 Warto wskazać, że W. Litewski (op. cit., s. 141) wspomina o upośledzeniu kobiet na gruncie prawa prywatnego w kontekście ograniczenia zdolności prawnej. Nawet powołanie się Autorki na tego badacza nie uchroni jej przed krytycznym odbiorem tego pytania, chociażby z uwagi na fakt, że pytanie jest tak zredagowane, że nie można $\mathrm{z}$ jego treści wywnioskować, czy przesłanka płci, gdyby ją uznać za warunkującą o zdolności prawnej, odnosiła się do kobiet przez cały okres istnienia Imperium Romanum. O wpływie płci na zdolność prawną wspomina też W. Rozwadowski (op. cit. s. 94).

23 Odrębną kwestię stanowi problematyka filius familias, który dysponował peculium castrense, quasi castrense oraz adventicium.

24 Por. art. 65 ust. 1 ustawy z 6 lipca 1982 r. o księgach wieczystych i hipotece (Dz. U. 2001, Nr 124, poz. 1361 z późn. zm.).

25 Zob. I. Szpringer, Pierwszeństwo zastawów w prawie rzymskim, Lublin 2006, s. 12-13; por. W. Osuchowski, op. cit, s. 368; M. Kaser, Römisches Privatrecht ${ }^{14}$, München 1986, s. 141 i nast.; K. Kolańczyk, op. cit., s. 330; A. Guarino, op. cit., s. 749 i nast. (w szczeg. s. 753); G. Nicosia, op. cit., 
była stosowana wobec rzeczy ruchomych jest rażącym wprowadzeniem w błąd przyszłego adepta prawa pozytywnego ${ }^{26}$.

Nie można także zgodzić się Autorką w zakresie pytania 129, z treści którego wynika, że w przypadku nieformalnego wyzwolenia otrzymywało się status Latinus coloniarius (por. odp. na s. 221). Wyzwolenie per mensam, o którym jest mowa w pytaniu, powodowało nabycie przez osobę wyzwalaną stanowiska Latinus Iunianus, która miała jednak otwartą drogę do zostania civis Romanus ${ }^{27}$. Nie ulega wątpliwości, że w przedmiotowej kwestii doszło do pomieszania kategorii Latynów, co w konsekwencji doprowadziło do błędnej odpowiedzi na to pytanie. Warto podkreślić, że wśród propozycji do wyboru można znaleźć odpowiedź prawidłową (odp. a), ale nawet gdy się ją wybierze, a następnie zweryfikuje wybór w kluczu odpowiedzi, okaże się, że był to niewłaściwy trop.

Sugestia dotycząca nadania obywatelstwa ${ }^{28}$ wszystkim wolnym mieszkańcom Rzymu na mocy constitutio Antoniniana jest ryzykowna i nie ma oparcia w zachowanych źródłach. Gaius w swoich Institutiones wskazał, że sytuacja prawna peregrini dedidicii była najgorsza, bowiem jako wolni mieli zamkniętą drogę do obywatelstwa rzymskiego $^{29}$. Nie wydaje się, aby w ciągu kilkudziesięciu lat dzielących Gaiusa i cesarza Karakallę doszło do włączenia tej kategorii do cives Romani. Z całą pewnością peregrini dedidicii zanikli w czasach Justyniana ${ }^{30}$. Prawdopodobne więc jest, że na mocy constitutio Antoniniana rzymskie obywatelstwo otrzymali prawie (podkr. P.K.) wszyscy wolni mieszkańcy Imperium Romanum, z wyjątkiem peregrini dedidicii. Pogląd ten w zdecydowanej większości jest ugruntowany wśród romanistów ${ }^{31}$.

s. 128-129; W. Litewski, op. cit., s. 244; A. Dębiński, op. cit., s. 255; M. Kuryłowicz, A. Wiliński, op. cit., s. 196; W. Wołodkiewicz, M. Zabłocka, op. cit., 165.

26 Trafnie istotę rzymskiego zastawu oddaje spostrzeżenie B. Biondiego (op. cit., s. 434): ...mentre nel diritto moderno pegno ed ipoteca sono istituti regolati in modo tanto diverso, che hanno in comune solo la funzione di garanzia, nel diritto romano sono istituti cosi uguali nel loro regime che possiamo parlare indifferentamente di pegno o di ipoteca...

27 G. 1, 29-34.

28 Ostatnio w kwestii zakresu nadania obywatelstwa rzymskiego w ramach constitutio Antoniniana

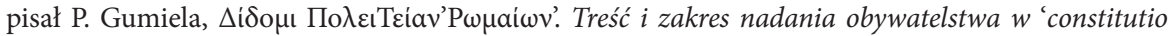
Antoniniana', „Zeszyty Prawnicze” [UKSW] 10.1, 2010, s. 129-147; zob. także: A. Łukaszewicz, Aegyptiaca Antoniniana. Działalność Karakalli w Egipcie (215-216), Warszawa 1993, s. 20 i nast.

29 G. 1, 26: Pessima itaque libertas eorum est, qui dediticiorum numero sunt; nec ulla lege aut senatus consulto aut constitutione principali aditus illis ad civitatem Romanam datur.

30 I. $1,5,3$.

31 R. Taubenschlag, op. cit., s. 114; W. Kunkel, op. cit., s. 86-87; W. Kunkel, M. Schermaier, Römische..., s. 80-81; W. Rozwadowski, op. cit., s. 90; K. Kolańczyk, op. cit., s. 197; A. Guarino, op. cit., s. 277; W. Litewski, op. cit., s. 137; A. Dębiński, op. cit., s. 150-151; M. Kuryłowicz, A. Wiliński, op. cit., s. 92; W. Wołodkiewicz, M. Zabłocka, op. cit., s. 77. Ostrożnie w tej kwestii wypowiedział się B. Biondi (op. cit., s. 130). Wydaje się, że Autorka podzieliła pogląd W. Osuchowskiego (op. cit., s. 238) w zakresie przyznania obywatelstwa wszystkim wolnym w drodze constitutio Antoniniana. Jako zagranicznych reprezentantów tego stwierdzenia można wskazać M. Kasera (op. cit., s. 31); V. Arangio-Ruiza (Storia..., s. 309, 338; także w pracy Istituzioni..., s. 55-56) czy G. Nicosia (op. cit., s. 49). 
Mylne jest wskazanie, że w prawie rzymskim pełną zdolność do czynności prawnych uzyskiwało się po ukończeniu 25 roku życia (por. pytanie 161 oraz odp. na s. 224). Należy podkreślić, że owa zdolność do czynności prawnych przysługiwała już chłopcom, którzy ukończyli 14 rok życia (w przypadku dziewczynek było to 12 lat) ${ }^{32}$. Jednakże z uwagi na niedoświadczenie życiowe wskazanych osób, prawo rzymskie, od czasu uchwalenia lex Laetoria $^{33}$ (początek II w. p.n.e.) przyznawało im ochronę w postaci m.in. exceptio legis Laetoriae. Trzeba jednoznacznie podkreślić, że osoby pomiędzy 14 a 25 rokiem życia (puberes minores viginti quinque annis) mogły dokonywać wszelkich czynności prawnych, bowiem nie doznawały ograniczenia w zakresie składania oświadczeń woli. Pomocą i radą miał służyć im curator minorum, który w przeciwieństwie do tutora udzielał przyzwolenia (consensus) do zawarcia określonej czynności prawnej. Jego rola nie była tak znacząca jak w przypadku tutora, bowiem dojrzali (puberes) nie byli związani jego stanowiskiem. Wydaje się, że w przypadku, gdy czynność prawna została dokonana z udziałem kuratora (być może niezależnie od tego, czy podopieczny skorzystał z jego pomocy bądź nie), pretor mógł odmówić przyznania ochrony w ramach lex Laetoria. W ten sposób minor zyskiwałby wiarygodność w oczach kontrahenta, który z kolei nie obawiałby się zaczepienia przez niego zawartej czynności prawnej. Warto podkreślić, że osoby, które ukończyły 25 rok życia, były na tyle doświadczone życiowo i gospodarczo, że nie potrzebowały doradztwa w osobie kuratora. Nie oznacza to jednak, że dopiero od tej chwili miały pełną zdolność do czynności prawnych, gdyż przysługiwała już im ona po ukończeniu 14 roku życia.

Za błędne należy uznać stanowisko Autorki, że czynność prawna osoby poniżej 25 roku życia była traktowana jako kulejąca (negotium claudicans) - por. pytanie 179 (oraz kuriozalną odpowiedź na s. 225). Trzeba podkreślić, że negotium claudicans pojawiała się w momencie, gdy impuberes (a zatem niedojrzały od 7 do 14 roku życia) zawierali czynność prawną powodującą jednocześnie przysporzenie oraz obciążenie ich majątku. Z pytania zaś można by wywnioskować, że negotium claudicans mógł dokonać, np. 19-letni Rzymianin sui iuris (wszak jest poniżej 25 roku życia), mający już pełną zdolność do czynności prawnych. Wydaje się, że, redagując pytanie w przedstawionym kształcie, wypaczono kwestię zdolności do czynności prawnych na gruncie prawa rzymskiego $^{34}$.

32 R. Taubenschlag, op. cit., s. 119-120; B. Biondi, op. cit., s. 134-135; M. Kaser, op. cit., s. 75-76; W. Rozwadowski, op. cit., s. 110; K. Kolańczyk, op. cit., s. 208-209; A. Guarino, op. cit., s. 332-338; G. Nicosia, op. cit., s. 59-62; W. Litewski, op. cit., s. 143-144; A. Dębiński, op. cit., s. 159-160; M. Kuryłowicz, A. Wiliński, op. cit., s. 102; W. Wołodkiewicz, M. Zabłocka, op. cit., s. 114-115.

33 Podstawowe informacje o tej lex podaje G. Rotondi, Leges publicae populi Romani. Elenco cronologico con una intoduzione sullattività legislativa dei comizi romani, Milano 1912 (Nachdruck Hildesheim 1966), s. 271-272.

34 Na marginesie należy dodać, że pytanie 162, korespondujące z przedstawionymi rozważaniami, jest również błędnie skonstruowane. 15-letni chłopak, zaciągając pożyczkę, nie zawarł czynności kulejącej (por. pytanie 162), która do swej ważności wymagała zgody opiekuna w postaci auctoritas tutoris. Tutela była przewidziana dla niedojrzałych osób sui iuris (chłopcy i dziewczynki) oraz dla 
Istotnym walorem dydaktycznym prawa rzymskiego jest przedstawienie studentowi prawa podstawowych instytucji prawnych, obecnych we współczesnych kodyfikacjach prywatnoprawnych. Zaliczyć do nich można nie tylko kwestię własności, posiadania, konstrukcję zobowiązania, czy problematykę dziedziczenia, ale także treści ogólne jak chociażby warunek (condicio) oraz termin (dies). Pytania odnoszące się do ostatnio wskazanych instytucji znajdują się w recenzowanym zbiorze. Niestety, niepokój budzi ich poziom merytoryczny. W pytaniu 233 wskazano, że warunkiem jest „...zdarzenie przyszłe i niepewne...”, natomiast w kolejnym, że terminem jest „...zdarzenie przyszłe, ale pewne..." (por. odp. na s. 230).

Trzeba podkreślić, że taki kształt pytań wypacza obie te instytucje prawne. Nic bowiem nie wynika, pod względem skutków prawnych, z określenia warunku i terminu w przedstawiony sposób. Warto wskazać, że dla oceny czynności prawnej zawartej z zastrzeżeniem condicio albo dies miarodajny jest moment ziszczenia się owego zdarzenia przyszłego niepewnego (warunek) bądź przyszłego pewnego (termin). Nie ulega więc wątpliwości, że czynność prawna jest od samego początku ważna, a jedynie skutki prawne strony uzależniają od spełnienia wskazanych zdarzeń. Brak ukazania w pytaniu wpływu warunku i terminu na zakres skuteczności zawartej czynności prawnej jest sporym uproszczeniem. Warto zaznaczyć, że konstrukcja warunku i ter-

dojrzałych kobiet (tutela mulierum). Stąd też wskazanie, że 15-letni chłopak do ważności czynności prawnej musiał otrzymać interpositio auctoritatis tutoris jest niepoprawne. Skoro granicę pubertas stanowił ukończony 14 rok życia, to dysponując pełną zdolnością do czynności prawnych, mógł on złożyć oświadczenie woli skutkujące zaciągnięciem zobowiązania w postaci pożyczki (mutuum). Zatem do ważności czynności prawnej nie potrzebował interpositio auctoritatis tutoris, a przed złożeniem oświadczenia woli (gdyby sprawa działa się po uchwaleniu lex Laetoria) mógł zasięgnąć rady kuratora (consensus curatoris). Dlatego też odpowiedź podana jako prawidłowa (zob. s. 224) jest nietrafna, a właściwa wydaje się jedna z propozycji (odp. a). Należy także odnieść się do pytania 163, z treści którego wynika, że 18-letnia kobieta nie mogła sporządzić testamentu, bowiem była zaliczana do impuberes, a sporządzony przez nią dokument był bezskuteczny. Warto nadmienić, że ukończony 18 rok życia nie pozwala na zakwalifikowanie tej osoby jako niedojrzałej (w kluczu odpowiedzi mówi się już o impuberes infantia maiores). Ma rację Autorka stwierdzając, że testament jest bezskuteczny, lecz wynika to z zupełnie innej okoliczności, tzn. z konieczności udzielenia interpositio auctoritatis tutoris, bowiem kobiety podlegały tutela mulierum (szerzej o zanikaniu tutela mulierum zob. M. Zabłocka, Zanikanie instytucji tutela mulierum w prawie rzymskim, PK 30 (1987, nr 3-4, s. 239-252). Podobną uwagę należy uczynić w przypadku pytania 177, odnoszącego się do emptio-venditio, dokonanej przez 18-letnią dziewczynę (kobietę). Autorka przyjęła, że ta czynność prawna wymaga potwierdzenia przez opiekuna, bowiem samodzielnie mogła dokonać tylko czynności przysparzającej (odp. d - por. s. 225). Należy pokreślić, że pytanie nie jest sformułowane precyzyjnie, bo nic nie wspomniano o przedmiocie emptio-venditio, a kwestia ta nie jest bez znaczenia. Trzeba podkreślić, że w przypadku, gdy była to drobna rzecz (np. amfora, waza, artykuły życia codziennego, etc.) aktywność tutora nie była konieczna (G. 1, 190: ...mulieres enim, quae perfectae aetatis sunt, ipsae sibi negotia tractant... - bez wątpienia 18-letnia dziewczyna była już od 6 lat osobą dojrzałą). Wiązało się to bezpośrednio z jego rolą, tzn. pomaganiu kobietom w przypadku zawierania czynności prawnych większej wagi (np. zaciągnięcie zobowiązania w większej kwocie, nabycie niewolników, etc.). 
$\mathrm{minu}^{35}$, obecna na gruncie polskiego prawa pozytywnego ${ }^{36}$, jest głęboko osadzona w prawie rzymskim ${ }^{37}$.

Prawo rzeczowe (wraz z iura in re aliena) jawi się jako jeden $\mathrm{z}$ trudniejszych do opanowania przez studenta działów prawa rzymskiego. Stąd też można by liczyć na to, że przedmiotowy wybór pytań wyjdzie naprzeciw tym trudnościom przez adekwatny dobór materii. Jednakże zabrakło chociażby pytań dotyczących podstawowych zasad prawa rzeczowego (nemo plus iuris in alium transferre potest, quam ipse haberet, superficies solo cedit, neminem sibi ipsum causam possessionis mutare posse, czy spotykana $\mathrm{w}$ polskim ustawodawstwie zasada prior tempore, potior iure). Wydaje się, że zbyt mało miejsca poświęcono też iura in re aliena (por. pytania 399-410), a przede wszystkim zastawowi, instytucji niezwykle istotnej z punktu widzenia obrotu prawnego (nie tylko antycznego), ale szalenie trudnej. Zaproponowany wybór pytań w tej ostatniej kwestii (pytania 408-410) jest niewystarczający, a już z całą pewnością nie umożliwia powtórki wiedzy dotyczącej tej instytucji. Ponadto student nie znajdzie tutaj także żadnego pytania, które pozwoli mu sprawdzić zasób wiadomości z zakresu różnic między służebnością gruntową a osobistą. Wydaje się, że jest to ważna problematyka, obecna także $\mathrm{w}$ polskiej legislacji ${ }^{38}$. Zdziwienie budzi całkowite pominięcie milczeniem podstawowych cech własności (tj. elastyczności, bezwzględności), a także brak wskazania na fundamentalne reżimy nabycia praw do rzeczy, tj. nabycie pochodne oraz pierwotne. Wydaje się, że nie są to kwestie na tyle oczywiste, by można zrezygnować z pytania o nie. Praktyka pokazuje, że zrozumienie bezwzględnego charakteru własności czy też elastyczności własności (nie wspominając już o różnicy między nabyciem pochodnym a pierwotnym) nastręczają sporych trudności. Ponadto trzeba podkreślić, że także w tym dziale doszło do uchybień ${ }^{39}$ i potknięć terminologicznych. Kuriozalne wydaje się tłumaczenie zasady accessio cedit principali („...przybytek dzieli los prawny rzeczy głównej...”). Raczej należało skłonić się ku powszechniej występującej translacji - „rzecz przyłączona przypada rzeczy głównej”40.

35 Zob. art. 116 ustawy z 23 kwietnia 1964 r. kodeks cywilny (Dz. U. 1964, Nr 16, poz. 93 z późn. zm.) - dalej: k.c. Szerzej w kwestii terminu na gruncie prawa prywatnego pisał Z. Radwański, Treść czynności prawnej. Termin, [w:] System prawa prywatnego, t. 2, red. Z. Radwański, Warszawa 2008, 277-283.

36 Por. art. 89 k.c.; zob. także: Z. Radwański, op. cit., s. 258-276.

37 I. $3,15,4$.

38 Por. art. 299 oraz art. 254, art. 266.

39 Nieporozumieniem jest pytanie o skutki prawne przetworzenia rzeczy (w czasach Hadriana - zob. pytanie 372), a następnie sugerowanie $\mathrm{w}$ odpowiedzi, że cesarz ten panował w okresie dominatu (por. s. 241). Dominat został wprowadzony w III w. n.e. przez Dioklecjana (por. A. Jurewicz, B. Sitek, Władza absolutna - dominat, [w:] Rzymskie prawo publiczne, red. B. Sitek, P. Krajewski, Olsztyn 2004, s. 58 i nast.; J. Zabłocki, A. Tarwacka, Publiczne prawo rzymskie, Warszawa 2005, s. 115 i nast.; A. Dębiński, J. Misztal-Konecka, M. Wójcik, op. cit., s. 59 i nast.), a panowanie Hadriana datuje się na II w. n.e.

40 Zob. przegląd dokonany przez R. Świrgoń-Skok, Nieruchomość i zasady akcesji według prawa rzymskiego, Rzeszów 2007, s. 56 przyp. 93. 
Nie można zgodzić się z sugestią Autorki, aby emfiteutę określać raz jako dzierżawcę (por. pytanie 324), a w innym miejscu jako dzierżawcę wieczystego (por. pytanie 331). Na gruncie prawa rzymskiego (podobnie jak i prawa polskiego) nie można traktować tych podmiotów synonimicznie. Dzierżawca, w przypadku prawa rzymskiego, to strona kontraktu najmu rzeczy (locatio conductio rei), a zatem strona stosunku obligacyjnego. Natomiast dzierżawca wieczysty (precyzyjniej: emfiteuta) to podmiot korzystający z jednego z iura in re aliena, tj. emfiteuzy. Tak więc wyraźnie widać, że obie kategorie podmiotów nie są tożsame, o czym przede wszystkim przesądza odmienny reżim prawny, kształtujący ich uprawnienia i obowiązki. Stąd też błędne jest postrzeganie przez ten sam pryzmat dzierżawcy i emfiteuty, bowiem takie działanie wprowadza niepotrzebny nieporządek terminologiczny, prowadzący do zagmatwania - jak się wydaje - precyzyjnego odróżnienia tych podmiotów prawa.

Jeszcze większą obiekcję rodzi lektura pytania 338, gdzie dokonano rozróżnienia własności bonitarnej i kwirytarnej, stosując kryterium podmiotowo-przedmiotowe. Nie wydaje się to trafną propozycją. Należy zważyć, że zarówno podmiotem własności kwirytarnej oraz bonitarnej był Rzymianin, podczas gdy peregrynowi przysługiwała wyłącznie własność bonitarna. Ponadto, w przypadku kryterium przedmiotowego można wskazać istotną różnicę. Własność kwirytarna jak i bonitarna dotyczyła res mancipi, z tym że rozbieżność dotyczyła czynności prawnej towarzyszącej przeniesieniu prawa własności. Odnośnie do dominium ex iure Quiritim należało skorzystać z formalistycznych aktów - mancipatio oraz in iure cessio (dla res mancipi) i nieformalnej traditio (dla res nec mancipi), aby odnieść oczekiwany skutek prawnorzeczowy ( $\mathrm{tj}$. przeniesienie własności). Natomiast własność bonitarna powstawała wtedy, gdy res mancipi nie została wydana poprzez mancipatio lub in iure cessio. Nabywca rzeczy miał ją w swoim majątku (in bonis), a prawo własności (w świetle ius civile) przysługiwało dalej zbywcy. Stąd też nabywca był traktowany jako possessor ad usucapionem (possessio civilis), bowiem dopiero wtedy, gdy spełnione zostały wszystkie przesłanki zasiedzenia, mógł władać rzeczą jak właściciel kwirytarny. Już zatem z tej krótkiej charakterystyki własności bonitarnej i kwirytarnej widać, że zastosowane przez Autorkę kryterium podziału jest nieprecyzyjne. Bliższy prawdzie i w zasadzie jedyny z prawidłowych wariantów odpowiedzi, powinien być ten odnoszący się do odmiennego zakresu ochrony tych stosunków rzeczowych (por. odp. c - uznaną za niewłaściwą, zgodnie z kluczem odpowiedzi). Źródło ochrony dominium ex iure Quiritium stanowiło ius civile (rei vindicatio oraz actio negatoria), podczas gdy ius honorarium (z actio Publiciana) starało się chronić interesy właściciela bonitarnego. Warto jednak podkreślić, że z pretorskiej actio Publiciana mógł korzystać nie tylko peregryn, ale także Rzymianin, obawiający się o pozytywny efekt probatio diabolica w przypadku skorzystania z rei vindicatio. Stąd też podstawowym kryterium warunkującym rozróżnienie na własność kwirytarną i bonitarną nie było to odnoszące się do kwestii przedmiotowo-podmiotowych, ale dotyczące odmiennej sfery ochrony obu „rodzajów” własności. 
Sporo zastrzeżeń należy skierować pod adresem pytań zawartych w kolejnym dziale, bodaj najistotniejszym i najtrudniejszym - tj. zobowiązań. Podstawową konstatację rodzi zamienne używanie w treści pytań, na określenie źródła zobowiązania, terminu „umowa” oraz „kontrakt”41. Wydaje się, że traktowanie tych pojęć na gruncie prawa rzymskiego jako synonimów jest nieadekwatne.

Brak precyzji należy podnieść przy redakcji pytania 451, dotyczącego świadczenia in specie. Odnosząc się do tej kwestii należy wskazać, że nie jest do końca prawdziwe twierdzenie, że przypadkowa utrata res in specie „...powodowała niemożliwość świadczenia i wygaśnięcie zobowiązania.... W tak sformułowanym wariancie odpowiedzi (zdaniem Autorki - poprawnym, zob. s. 249) została pominięta problematyka wpływu dłużnika na utratę przedmiotu świadczenia w postaci res in specie. Okoliczność ta jest szalenie istotna, bowiem w przypadku, gdy debitor przyczynił się w jakikolwiek sposób do zniszczenia, uszkodzenia, utraty, etc. res in specie, pierwotny węzeł obligacyjny (opierający się na dare, facere, czy też prastare) przekształcał się w obowiązek odszkodowawczy, w zależności od stopnia zawinienia dłużnika (praestare dolum, praestare culpam, praestare custodiam). Pominięcie tej okoliczność w przedmiotowym pytaniu zdaje się sugerować, że niewykonanie świadczenia in specie, niezależnie od zaangażowania i nastawienia dłużnika, skutkowało wygaśnięciem zobowiązania. Uproszczenie odpowiedzi prowadzi do wypaczenia odpowiedzialności odszkodowawczej dłużnika w zobowiązaniach kontraktowych.

Podobne zastrzeżenie merytoryczne należy uczynić w przypadku pytania 455, dotyczącego upoważnienia przemiennego (facultas alternativa). Nie jest poprawne wskazanie w prawidłowym wariancie odpowiedzi d (zob. s. 249), że zobowiązanie gasło, gdy dłużnik wybrał świadczenie w celu zwolnienia się z vinculum iuris, ale stało się ono niemożliwe do spełnienia. Zabrakło wskazania, czy wpływ dłużnika na niemożliwość spełnienia świadczenia odgrywa jakąś rolę, bowiem z konstrukcji pytania wynika, że nie był on istotny. Kwestia ta nie jest jednak bez znaczenia. Gdy niewolnik wyrządził szkodę, to właściciel (stając się dłużnikiem) miał możliwość wydania go w ramach noxae datio lub mógł zwolnić się z vinculum iuris poprzez zapłatę kary prywatnej. Jeżeli skłonił się ku pierwszemu wariantowi, a następnie świadomie uśmiercił niewolnika (np. podając mu truciznę), zobowiązanie z pewnością nie wygasało. Wydaje się więc, że powinno się wspomnieć o potencjalnym wpływie dłużnika na niemożliwość świadczenia, tak aby ukazać studentowi pełny obraz facultas alternativa. W rzeczy samej, zobowiązanie wygasało, gdy dłużnik dokonał wyboru świadczenia, a niemożliwość dare, facere, prastare oportere była następstwem zdarzeń, co do których nie można mu przypisać winy.

Konstrukcja wielu współczesnych instytucji prawa zobowiązań ma swoje korzenie $\mathrm{w}$ prawie rzymskim. Bez wątpienia jest to widoczne w przypadku solidarności.

41 Por. pytania: 418, 419, 420, 428, 429, 435, 436, 437, 445, 447, 551, 552, 563, 579, 582, 602. 
Warto jednak podkreślić, że istniała jednak różnica między antyczną konstrukcją solidarności biernej, a jej aktualnym kształtem, zawartym w kodeksie cywilnym. Źródła prawnicze $^{42}$ dowodzą, że w prawie rzymskim wierzyciel miał uprawnienie żądania od jednego z wybranych dłużników spełnienia całego świadczenia, co tym samym umarzało zobowiązanie wobec pozostałych ${ }^{43}$. Tymczasem w pytaniu 503 sugeruje się, że solidarnośćc ${ }^{44}$ bierna polega na tym, iż „...wierzyciel może żądać spełnienia świadczenia w całości lub części od wszystkich, kilku z nich lub każdego z osobna, wedle własnego wyboru, a spełnienie całości świadczenia przez jednego z dłużników zwalnia pozostałych.... Lektura tego pytania nasuwa skojarzenia - jak się okazuje słuszne ${ }^{45}$ - z polskim kodeksem cywilnym. Wydaje się jednak, że konstrukcja solidarności biernej przedstawia się nieco odmiennie w prawie polskim niż w prawie rzymskim. Wskazane źródła nie wspominają o uprawnieniu wierzyciela do żądania części świadczenia od kilku dłużników, a mówią o spełnieniu całości przez jednego, wybranego przez niego. Faktem jest, że w czasach Justyniana doszło do modyfikacji konstrukcji solidarności w ten sposób, że dłużnik pozwany mógł żądać podziału wierzytelności pomiędzy wypłacalnych współdłużników ${ }^{46}$. Jednakże jest to okres prawa poklasycznego, a zatem przedstawiona zmiana pojawiła się stosunkowo późno. Poza tym nie wskazano okresu, do jakiego odnosi się pytanie, stąd też należy domniemywać, że chodzi tu o prawo klasyczne. Jednak w tym kontekście zaproponowana konstrukcja solidarności biernej jest niepoprawna i nie ma odzwierciedlenia w zachowanych źródłach.

Zupełnie zbędne jest przedstawianie kilku pytań odnoszących się do tej samej materii ${ }^{47}$. Nie dość, że pojawiają się one najczęściej po sobie, to niewiele wnoszą w utrwalenie wiedzy studenta. Wydaje się, że lepiej było z nich zrezygnować i na ich miejsce wprowadzić inne, bowiem także w przypadku zobowiązań są dość istotne luki. Warto

42 D. 45, 2, 3, 1 (Ulpianus libro quadragesimo septimo ad Sabinum): Ubi duo rei facti sunt, potest vel ab uno eorum solidum peti: hoc est enim duorum reorum, ut unusquisque eorum in solidum sit obligatus possitque ab alterutro peti...; I. 3, 16, 1: Ex huiusmodi obligationibus et stipulantibus solidum singulis debetur et promittentes singuli in solidum tenentur. in utraque tamen obligatione una res vertitur: et vel alter debitum accipiendo vel alter solvendo omnium perimit obligationem et omnes liberat. Ex duobus reis promittendi alius pure, alius in diem vel sub condicione obligari potest: nec impedimento erit dies aut condicio, quo minus ab eo qui pure obligatus est petatur.

43 Por. R. Taubenschlag, op. cit., s. 176; B. Biondi, op. cit., s. 389 i nast.; W. Osuchowski, op. cit., s. 475; W. Rozwadowski, op. cit., s. 153; K. Kolańczyk, op. cit., s. 344; A. Guarino, op. cit., s. 790 i nast.; W. Litewski, op. cit., s. 268; V. Arangio-Ruiz, Istituzioni..., s. 420 i nast.; A. Dębiński, op. cit., s. 265; M. Kuryłowicz, A. Wiliński, op. cit., s. 209; W. Wołodkiewicz, M. Zabłocka, op. cit., s. 212.

44 Uwagi uczynione na gruncie solidarności biernej, można - odpowiednio - odnieść do solidarności czynnej.

45 Por. art. $366 \$ 1$ k.c.

46 Zob. B. Biondi, op. cit., s. 389-390; por. W. Osuchowski, op. cit., s. 475.

47 Por. np. pytania 381 oraz 384 (referujące do obrotu res furtiva); 448, 450, 452 dotyczące zasady genus perire non censetur; pytania 417 i 444 odnoszące się do alteri stipulari non potest; 553 oraz 556 (dotyczące zastrzeżenia terminu na korzyść dłużnika). Podobnie jest w przypadku pytań dotyczących spadków - zob. pytania 640-641 (odnoszące się do śmierci mandatariusza); 643 oraz 688 dotyczące odpowiedzialności za długi spadkowe. 
nadmienić, że zupełnie została pominięta kwestia odpowiedzialności za wady ${ }^{48}$ prawne sprzedanej rzeczy. Wpływ prawa rzymskiego na tę instytucję jest na tyle fundamentalny ${ }^{49}$, że należało poświęcić jej chociażby symboliczne pytanie. Niewiele też student dowie się o względnym charakterze zobowiązania i cechach odróżniających rzymską obligatio od prawa rzeczowego. Wypadałoby także więcej uwagi poświęcić obligationes ex delicto (oraz quasi ex delicto) ${ }^{50}$, czy quasi ex contractu, bowiem ta problematyka jest niesłychanie skąpo poruszana w recenzowanym zbiorze, a przyswojenie jej nie należy do najłatwiejszego zadania. Autorka wyjątkowo obszernie przedstawiała pytania odnoszące się do tzw. części ogólnej zobowiązań (podmiot, przedmiot zobowiązania, świadczenie, wina, szkoda, potrącenie, etc.), a zdecydowanie mniej pytań dotyczy poszczególnych zobowiązań. Nie ulega wątpliwości, że zarówno część ogólna jak i szczególna są istotne z punktu widzenia wiedzy studenta prawa, lecz należało zachować adekwatne proporcje w obu tych kwestiach.

Pytania odnoszące się do prawa spadkowego również nie są wolne od usterek i błędów. Niezrozumienie budzi konstrukcja pytania 630, które ma za zadanie zbadać wiedzę z zakresu dziedziczenia ustawowego ${ }^{51}$. Na marginesie trzeba podnieść, że stosowanie takiej nomenklatury do dziedziczenia $a b$ intestato na gruncie prawa rzymskiego jest wyjątkowo mylące. Jedyną ustawą regulującą ten reżim sukcesji uniwersalnej była lex duodecim tabularum. Obok niej istniały też inne regulacje prawne, poświęcone tej kwestii, chociażby edykt pretorski. Stąd też wydaje się, że z punktu widzenia prawa rzymskiego lepiej jest mówić o dziedziczeniu beztestamentowym niż ustawowym, bowiem

48 Odpowiedzialność za wady fizyczne rzeczy to treść pytań 606-608.

49 Zob. art. $556 \$ 2$ k.c.

50 Warto wskazać, że na określenie quasi-deliktu effusum vel deicetum użyto nietypowej i wydaje się, że zupełnie nieoddającej charakteru tego czynu, nomenklatury, nazywając go defusio (por. pytanie 492). Leksykalne znacznie tego rzeczownika („wylewanie”, „rozlewanie”, np. wina z większych naczyń do mniejszych - M. Plezia, op. cit., t. II, s.v. defusio, s. 61; „wylew”, „rozlewanie” - J. Sondel, op. cit., s.v. defusio, s. 260) ma wprawdzie odniesienie do wylewania cieczy, lecz chyba raczej nie z pomieszczenia, jak jest to w przypadku przedmiotowego quasi-deliktu. Dość wspomnieć, że jest to terminologia, którą nie posługują się romaniści, a przez to niewłaściwe jest stosowanie tego typu określeń w zbiorze, który ma na celu rekapitulację nabytej przez studenta wiedzy. Zbliżoną uwagę należy uczynić pod adresem pytania 494, w którym doszło do pomieszania odpowiedzialności właścicieli statków, zajazdów, oberży za kradzieże rzeczy, wniesionych przez klientów, jakich dopuścił się personel (exercitores aut navis aut caupoae aut stabuli de damno aut furto) z receptum nautarum, cauponum, stabulariorum. Nie można zgodzić się z sugestią Autorki, że odpowiedzialność właścicieli statków, etc. jest tożsama z receptum. Trzeba podnieść, że receptum spełniało funkcję gwarancyjną, a tym samym zaostrzało odpowiedzialność wskazanych podmiotów, prowadzących działalność niecieszącą się dużym zaufaniem Rzymian, właśnie ze względu na możliwość wyrządzenia szkody, najczęściej przez personel tam zatrudniony. Natomiast wyrządzenie szkody w przypadku popełnienia quasi-deliktu exercitores navis itd. uprawniało poszkodowanego do wniesienia skargi i żądania odszkodowania in duplum. Całe pytanie brzmiałoby poprawnie, gdyby zrezygnowano z umieszczenia w nawiasie terminu receptum, jako łacińskiego odpowiednika odpowiedzialności właścicieli statków itd., bowiem synonimiczne postrzeganie obu zdarzeń jest niepoprawne.

51 Warto nadmienić, że tej nomenklatury Autorka używa w dalszej części zbioru, zob. pytanie 721. 
ta fraza lepiej oddaje ducha rzymskiego prawa spadkowego. Podniesiona uwaga nie jest aż tak istotna, biorąc pod uwagę merytoryczną część pytania, jednak zasadne zdaje się wspomnienie o tej kwestii w tym miejscu. Sama treść pytania 630 budzi niepokój, bowiem za prawidłową odpowiedź (zob. s. 266) Autorka uważa tę, która w następujący sposób charakteryzuje dziedziczenie $a b$ intestato - „...zachodziło niezależnie od woli spadkodawcy, a czasem wbrew woli spadkodawcy.... Z lektury tej odpowiedzi zdaje się wynikać, że wola spadkodawcy była drugorzędna; czyżby zatem dziedziczenie beztestamentowe miało wyprzedzać sukcesję uniwersalną na podstawie testamentu? Warto jednak podkreślić, że taka sugestia jest błędna w świetle zachowanych źródeł ${ }^{52}$. Ponadto jedną z naczelnych zasad rzymskiego prawa spadkowego była swoboda testowania, co w naturalny sposób pozwala przyjąć trafne założenie, że w praktyce było odwrotnie, tzn. dziedziczenie testamentowe wyprzedzało reżim $a b$ intestato. Godne odnotowania jest także to, że wypracowana przez Rzymian hierarchia w tej materii, jest także obecna w zdecydowanej większości współczesnych systemów prawnych.

Zasadne jest także pochylenie się nad drugim członem zaproponowanej odpowiedzi. Nie bez znaczenia będzie tutaj także przywołanie kolejnego pytania, 631. W kluczu odpowiedzi wskazano, że dziedziczenie wbrew woli spadkodawcy zachodzi wtedy, gdy testament jest nieważny (por. s. 266). Jest to zarazem najprostszy wariant, niweczący wolę spadkodawcy wyrażoną w testamencie. O wiele bardziej skomplikowana jest kwestia dziedziczenia przeciwtestamentowego, którego dotyczy pytanie 631. Warto zaznaczyć, że romaniści wyróżniają dwie odmiany tego trybu dziedziczenia - dziedziczenie przeciwtestamentowe formalne oraz materiale ${ }^{53}$. Niestety, nieprecyzyjnie sformułowane pytanie nie pozwala wskazać, o jaki reżim chodzi. Jednakże nawet ten mankament byłby mało znaczący, gdyby sugerowana przez Autorkę odpowiedź pokrywała się z prawidłowym pojmowaniem dziedziczenia przeciwtestamentowego.

Odnosząc się do dziedziczenia przeciwtestamentowego formalnego należy podnieść, że właśnie w tym przypadku dochodziło do sukcesji wbrew woli testatora, gdy pominął on inne osoby z kręgu sui heredes niż syna. Wtedy testament pozostawał w mocy, a pominięci dochodzili do spadku kosztem dziedziców testamentowych ${ }^{54}$. Zatem błędna jest sugestia Autorki, że ten tryb dziedziczenia dochodził do skutku, gdy testament okazał się nieważny (por. odp. na s. 266). Było wręcz przeciwnie, pominięte osoby dochodziły do spadku kosztem dziedziców wymienionych w testamencie.

Zupełnie nie można zgodzić się z treścią pytania 717, odnoszącego się do instytucji zachowku (pars legitima, portio debita). Pierwsze zastrzeżenie budzi już kwestia

52 D. 34, 4, 4 (Ulpianus libro tricesimo tertio ad Sabinum): ...ambulatoria enim est voluntas defuncti usque ad vitae supremum exitum.

53 Por. R. Taubenschlag, op. cit., s. 287-289; W. Osuchowski, op. cit., s. 522-528; B. Biondi, op. cit., s. 741-749; W. Rozwadowski, op. cit., s. 219-221; K. Kolańczyk, op. cit., s. 481-484; A. Guarino, op. cit., s. 448-453; G. Nicosia, op. cit., s. 327-329; W. Litewski, op. cit., s. 331-336; V. Arangio-Ruiz, Storia..., s. 544-550; A. Dębiński, op. cit., s. 345-347; M. Kuryłowicz, A. Wiliński, op. cit., s. 149-152; W. Wołodkiewicz, M. Zabłocka, op. cit., s. 181-183.

54 Zob. G. 2, 124. 
uproszczenia pars legitima poprzez definiowanie go jako „...część udziału spadkowego...”. W istocie, nie można odmówić Autorce części prawdy, ale także nie można uznać określenia zachowku za poprawne. Z pewnością zabrakło tu doprecyzowania owego udziału spadkowego. Należało wskazać, że zachowek stanowi tę masę spadkową, która przypadłaby uprawnionemu doń podmiotowi, gdyby doszło do dziedziczenia ab intestato. Natomiast wyliczenie portio debita jest następstwem nieskomplikowanej operacji matematycznej, sprowadzającej się do pomnożenia odpowiedniego ułamka należnej masy spadkowej w dziedziczeniu beztestamentowym (np. dla okresu klasycznego była to $1 / 4$ ) poprzez liczbę doń uprawnionych z zachowaniem zasady dziedziczenia in capita (oraz in stripes). Druga uwaga, jaką należy sformułować pod adresem tegoż pytania, to kwestia ułamka, jaki miałby być przedmiotem wskazanej operacji. W treści pytania zabrakło informacji, jakiego okresu dotyczy pytanie, a nie jest to sprawa drugorzędna. Jego lektura pozwala wskazać dwie poprawne odpowiedzi - wielkość 1/3 (odp. c) wprowadzoną przez Justyniana, oraz ułamek 1/4 charakterystyczny dla prawa klasycznego (odp. a). Klucz odpowiedzi nie pozostawia złudzeń, że chodziło o okres klasyczny (por. 272). Wydaje się więc, że w treści pytania powinna być informacja, do jakiego okresu prawa rzymskiego należy odnieść wysokość ułamka.

Nie sposób jest nie odnotować wyjątkowo skąpej ilości pytań poświęconych instytucji legatów i fideikomisów. Trudno jest wytłumaczyć ten krok Autorki. Wydawać by się mogło, że jest to materia na tyle wdzięczna, że śmiało mogła posłużyć za kościec kilku pytań - np. odwołania się do instytucji legatu jako quasi-kontraktu, co zarazem byłoby swoistą powtórką prawa zobowiązań. Warto by też było pokusić się o rozróżnienie skutków prawnych w zakresie nabycia prawa do rzeczy z poszczególnych legatów albo wskazać właściwy moment nabycia praw do rzeczy przez legatariusza. Na próżno jednak szukać takich pytań w zbiorze, bowiem legatom i fideikomisom poświęcono po jednym pytaniu (sic!).

Umieszczenie pytań poświęconych szeroko pojętym stosunkom familijnym w końcowej części recenzowanego zbioru, było już przedmiotem zasygnalizowania na wcześniejszych kartach. W tym miejscu zasadne będzie przedstawienie merytorycznej zawartości wybranych spośród nich.

Należy podkreślić, że redakcja tych pytań wypada nadzwyczaj pozytywnie na tle wcześniej omawianych działów prawa rzymskiego. Wydaje się, że wiąże się to z niezbyt dużym stopniem zawiłości przedmiotowej materii w porównaniu do prawa rzeczowego czy zobowiązań.

Odnosząc się do pytania 795 nie sposób nie wytknąć używania błędnej terminologii zastosowanej w celu zdefiniowania instytucji posagu (dos). Wydaje się, że nie jest do końca poprawne nazwanie posagu jako „...darowizny żony na rzecz męża dla ułatwienia mu ponoszenia ciężarów małżeństwa.... W źródłach ${ }^{55}$ jest jedynie mowa

55 D. 23, 56, 3, 1 (Paulus libro sexto ad Plautium): Ibi dos esse debet, ubi onera matrimonii sunt. Instytucją posagu, w różnych aspektach, zajmowała się obszernie A. Stępkowska, Ustanowienie a ukonstytuowanie się posagu w rzymskim prawie klasycznym, „Zeszyty Prawnicze” [UKSW] 6.1, 
o celu, jakiemu miał służyć posag, tj. ustanawiano go po to, aby ułatwić ponoszenie ciężarów małżeństwa (onera matrimoni). Trafniej jest chyba określać dos jako przysporzenie majątkowe dokonywane przez żonę bądź inną uprawnioną osobę na rzecz męża. Tym samym nie wprowadza to chaosu terminologicznego obu tych instytucji - tj. darowizny (donatio $)^{56}$ oraz posagu (dos). Sugestia w tej materii jest nietrafiona i dodatkowo zaciera $\mathrm{w}$ świadomości studenta istotę funkcjonującego $\mathrm{w}$ prawie klasycznym zakazu małżeńskich darowizn ${ }^{57}$. Zupełnie odrębną kwestią jest także zawężenie kręgu podmiotów uprawnionych do ustanowienia posagu. Redakcja pytania zdaje się dowodzić, że posag ustanawiała wyłącznie żona. Takie postrzeganie tej instytucji stoi w sprzeczności do zachowanych źródeł, z lektury których wynika, że posag mógł ustanowić ojciec kobiety (dos profecticia) bądź ktokolwiek inny, a więc i kobieta, gdy była sui iuris (dos adventicia $)^{58}$. Nie ulega więc wątpliwości, że przedmiotowe pytanie zostało sformułowane nadzwyczaj lakonicznie i nieprecyzyjnie.

Niepokoi także merytoryczna strona pytania 844, odnoszącego się do domniemania ojcostwa. Wydaje się, że zaproponowana interpretacja paremii pater is est quem nuptiae demonstrant jest niewłaściwa. Nie można bowiem zgodzić się, że oznacza ona domniemanie urodzenia dziecka w małżeństwie najwcześniej w 7 miesiącu po jego zawarciu, a najpóźniej w 10 miesiącu po jego rozwiązaniu (por. s. 195) ${ }^{59}$. Wydaje się, że ukazanie prawidłowej interpretacji tej zasady będzie możliwe po przyjrzeniu się fragmentowi źródłowemu ${ }^{60}$, z jakiego została zaczerpnięta. Wypowiedź Paulusa nie budzi wątpliwości w przedmiocie jej analizy. Zdaniem jurysty, matka zawsze jest pewna, tzn. każde dziec-

2006, s. 195-218; eadem, „Dos recepticia” i „dos aestimata” w świetle „Lex Iulia de fundo dotali”, „Studia Prawnoustrojowe” 2007, t. 7, s. 203-217; eadem, Zakaz alienacji gruntów posagowych w rzymskim prawie klasycznym, CPH 59.2, 2007, s. 21-43; eadem, Zakaz obciażania nieruchomości posagowych w rzymskim prawie klasycznym, „Zeszyty Prawnicze” [UKSW] 7.1, 2007, s. 7-21.

$56 \mathrm{~W}$ kontekście darowizny warto wskazać, że Autorka mija się z prawdą w pytaniu 790, twierdząc, że w prawie justyniańskim istniał zakaz darowizn między małżonkami (por. odp. na s. 278). Przeczy temu przede wszystkim odpowiedni pasus w Institutiones cesarza Justyniana - zob. I. 2, 7, 3, gdzie jasno zostały wskazane donationes propter nuptias, a także ugruntowany w literaturze romanistycznej pogląd w tej kwestii.

57 Zob. D. 24, 1, 1.

58 Por. Ulp. 6, 3: Dos aut "profecticia” dicitur, id est quam pater mulieris dedit; aut „adventicia”, id est ea, quae a quovis alio data est. Warto podkreślić, że dychotomia rodzajów posagów, wynikająca z cytowanego fragmentu, ma swoje głębsze konsekwencje w zakresie zwrotu dóbr posagowych. Wynika to $\mathrm{z}$ analizy kolejnych passusów Tituli ex corpore Ulpiani - Ulp. 6, 4: Mortua in matrimonio muliere dos a patre profecta ad patrem revertitur, quintis in singulos liberos in infinitum relictis penes virum. Quod si pater non sit, apud maritum remanet; Ulp. 6, 5: Adventicia autem dos semper penes maritum remanet, praeterquam si is, qui dedit, ut sibi redderetur, stipulatus fuit; quae dos specialiter „recepticia” dicitur.

59 Na marginesie należy wspomnieć, że bardziej zasadne jest posługiwanie się określeniem obu tych terminów w postaci konkretnego wymiaru dni, tzn. 182 dni po zawarciu małżeństwa rzymskiego, 300 dni po jego rozwiązaniu, por. A. Jurewicz, Domniemanie ojcostwa - ratio decidendi ustawodawcy, „Zeszyty Prawnicze” [UKSW] 6.1, 2006, s. 99.

60 D. 2, 4, 5 (Paulus libro quarto ad edictum): Quia semper certa est, etiam si volgo conceperit: pater vero is est, quem nuptiae demonstrant. 
ko ją posiada, natomiast ojcem jest ten, na którego wskazuje małżeństwo. Widać więc wyraźnie, że tekst źródłowy nie wspomina o żadnym czasokresie trwania ciąży i konsekwencjach z tym związanych. Stąd też nie można zgodzić się z interpretacją przedmiotowej paremii w zaproponowanym w pytaniu aspekcie. Wydaje się, że doszło tu do zlania się w jedność obu konstrukcji prawnych ${ }^{61}$, znanych Rzymianom, mających na celu ustalić małżeńskie pochodzenie dziecka ${ }^{62}$. Bardziej zasadne było zbudowanie odrębnych pytań poświęconych zarówno domniemaniu czasokresu trwania ciąży i skutków prawnych z tym związanych, jak i poprawnej interpretacji zasady pater is est quem nuptiae demonstrant.

Warto także odnotować wyjątkową wybiórczość materiału, jakiego dokonała Autorka w dziale poświęconym prawu rodzinnemu. Na wcześniejszych stronach ten mankament został podniesiony, a w tym miejscu wypada jedynie go doprecyzować. Uważny student nie znajdzie tu zbyt wielu pytań odnoszących się do wejścia pod patria potestas (poprzez adoptio bądź adrogatio, czy też legitymacji dziecka). Trudno jest także znaleźć w zbiorze pytania poświęcone wyjściu potomstwa spod władzy pater familias. Nie wydaje się, aby wskazana materia była tak oczywista, by pominąć ją milczeniem. Być może trzeba było kosztem innych pytań, nieraz zbyt ogólnych i powielających instytucję prawną ${ }^{63}$, pokusić się o szersze przedstawienie kwestionowanej partii materiału.

Recenzowany zbiór pytań zamyka wybór pytań poświęconych rzymskiemu procesowi prywatnemu. Przy ich redakcji wyjątkowo razi nadużywanie siatki pojęciowej charakterystycznej dla współczesnego procesu cywilnego. Sugerowanie studentowi (zazwyczaj) pierwszego roku prawa, wśród wariantów do wyboru, np. interwenienta ubocznego czy głównego (por. pytanie 870), odwoływania się do prawa materialnego i procesowego (por. pytanie 862), wspominanie o postępowaniu zabezpieczającym (por. pytanie 851) czy też mówienie o współuczestnictwie materialnym (bądź formalnym), jest zbyt jaskrawym odwołaniem się do prawa pozytywnego. Nie dość, że student nie zrozumie tych terminów, bowiem nie jest to siatka pojęciowa właściwa prawu rzymskiemu, to na dodatek nic nie wyniesie z pytań operujących tą terminologią. Stąd też z punktu widzenia dydaktyki prawa rzymskiego posługiwanie się wskazaną nomenklaturą jest niewskazane, bowiem student najczęściej styka się z nią po raz pierwszy w wyborze pytań, nie spotykając jej praktycznie na kartach podręczników, z jakich czerpał wiedzę. Bardziej zasadna była rezygnacja z pytań szafujących terminologią prawa pozytywnego na korzyść np. pytań poświęconych postępowaniu egzekucyjnemu czy fundamentalnej instytucji prawa procesowego, w pełni wykształconej w procesie kognicyjnym, tj. apelacji. Próżno jest poszukiwać w recenzowanym zbiorze pytań poświęconych ostatnio wskazanej kwestii.

61 Fragmenty źródłowe odnoszące się do czasokresu trwania ciąży i konsekwencji z tym związanych znajdują się w ustawie XII Tablic (Tab. IV, 4) oraz w Digesta Iustiniani - w szczególności D. 1, 5, 12. W obu brak jednak poszlaki, która pozwoliłaby Autorce na taką interpretację przedmiotowej paremii.

62 Szerzej w kwestii domniemania ojcostwa pisze A. Jurewicz, op. cit., s. 95 i nast.

63 Por. chociażby pytania poświęcone instytucji usus na gruncie prawa małżeńskiego - 763, 764, 772, 774 . 
$\mathrm{Na}$ marginesie należy wspomnieć, że nie zachowano symetrii $\mathrm{w}$ zakresie redakcji pytań odnoszących się do poszczególnych rodzajów procesu rzymskiego (legisakcyjny, formułkowy, kognicyjny). Proces kognicyjny został potraktowany „po macoszemu”, bowiem poświęcono mu tylko jedno (sic!) pytanie. Milczeniem zbyto znane prawu rzymskiemu postępowania szczegółowe, tj. proces reskryptowy czy episcopalis audientia. Symboliczne pytanie z tej materii dopełniłoby obrazu rzymskiego sądownictwa. Natomiast pytania odnoszące się do pozostałych form procesu są ze sobą przemieszane, co raczej nie może być postrzegane jako pozytywny zabieg. Wydaje się, że z punktu widzenia sprawdzenia wiedzy, lepiej było dokonać tematycznego układu pytań, co w znaczący sposób ułatwiłoby jej powtórkę i usystematyzowanie.

Również w tej ostatniej części zbioru nie uniknięto błędnie, nieprecyzyjnie zredagowanych pytań. Tytułem przykładu można wskazać pytanie 860, sprawdzające wiedzę z zakresu podmiotów piastujących funkcję sędziego. Dowiedzieć się z odpowiedzi na pytanie można, że sprawowali ją senatorowie ${ }^{64}$ i, jak się zdaje z konstrukcji pytania, były to jedyne podmioty ${ }^{65}$ mogące występować w tej roli. Niestety, jest to pogląd, który nie jest ugruntowany w badaniach romanistycznych. Zdecydowana większość romanistów stoi na stanowisku, że sędzia był osobą wybieraną przez strony z listy sędziów (album iudicum), a magistratus polecał objąć powierzoną funkcję bezstronnego rozjemcy sporu ${ }^{66}$. Stąd też nie można przyjąć, że propozycja redakcji tego pytania czyni zadość wiedzy, jaką student nabędzie w toku studiowania prawa rzymskiego.

Wydaje się także, że pytanie 870, odnoszące się do vindex, nie zostało rzetelnie zredagowane. Trudno jest bowiem ustalić, czy dotyczy postępowania egzekucyjnego, czy też odnosi się do fazy rozpoznawczej procesu rzymskiego. Kwestia ta nie jest bez znaczenia, bowiem vindex jest obecny w obu tych przypadkach ${ }^{67}$. Redakcja zaś pytania zdaje się

64 Za umocowaniem senatorów w roli sędziów opowiedzieli się W. Litewski, op. cit., s. 374, 389 oraz W. Osuchowski, op. cit., s. 153-155. Jednakże obaj romaniści wskazali, że taki stan rzeczy funkcjonował do czasów G. Grakchusa, który złamał ten monopol doprowadzając do uchwalenia (w formie plebiscytu) lex Sempronia iudiciaria (123 r. p.n.e.).

65 Nieprecyzyjna konstrukcja pytania, pozbawiona cezury czasowej, do której funkcję iudices sprawowali senatorowie, pozwala przyjąć, że mogli ją także piastować wskazani, jako potencjalnie błędne w przedmiotowym pytaniu podmioty, urzędnicy magistratury rzymskiej - tj. konsul i pretor. $\mathrm{W}$ istocie piastowali oni tę rolę do czasu wykształcenia się postępowania podzielonego na dwie fazy - tj. in iure oraz apud iudicem. Szerzej w tej kwestii zob. F. Serrao, Diritto privato, economia e società nella storia di Roma, t. I: Dalla società gentilizia alle origini delleconomia schiavistica, Napoli 2006, s. 423-436.

66 Por. B. Biondi, op. cit., s. 98, 105; L. Wenger, Institutes of the Roman Law of Civil Procedure (transl. O. Harrison Fisk), Littleton 1986, s. 60-62; M. Kaser, K. Hackl, Das römische Zivilprozessrecht ${ }^{2}$, München 1996, s. 56-60; K. Kolańczyk, op. cit., s. 108-109; A. Guarino, op. cit., s. 172-174; G. Nicosia, op. cit., s. 83, 86, 93, 95; C. Sanfilippo, Istituzioni di diritto romano ${ }^{10}$, Soveria Mannelli 2002, s. 118; V. Arangio-Ruiz, Istituzioni..., s. 108, 112; A. Dębiński, op. cit., s. 94-95; M. Kuryłowicz, A. Wiliński, op. cit., s. 62.

67 Szczegółowo rolę, jaką odgrywał vindex na fazy in iure procesu rzymskiego, omówili M. Kaser, K. Hackl, op. cit., s. 64 i nast.; zob. także: R. Taubenschlag, op. cit., s. 86; W. Osuchowski, op. cit., s. 158; L. Wenger, op. cit., s. 96-98; K. Kolańczyk, op. cit., s. 128; A. Guarino, op. cit., s. 172; W. Litewski, op. cit., s. 377; W. Wołodkiewicz, M. Zabłocka, op. cit., s. 290. 
wskazywać, że chodzi tu tylko o jego obecność i aktywność w początkowym etapie procesu rzymskiego. Warto jednak wspomnieć, że zdecydowana większość podręczników wspomina o tej postaci przy omawianiu skargi egzekucyjnej, jaką była legis actio per manus iniectionem ${ }^{68}$. Wydaje się, że właśnie ta rola vindex jest bardziej czytelna dla studenta. Chcąc jednak utrzymać kształt zaproponowanego w zbiorze pytania, należałoby je poprawić, tak aby nie brzmiało lakonicznie.

Należy podkreślić, że podniesione błędy merytoryczne zostały ograniczone tylko do najistotniejszych, najbardziej jaskrawych. Nie oznacza to jednak, że redakcja pozostałych pytań budzi pełną aprobatę. Zdarzają się także potknięcia w ich konstrukcji, mające lżejszy ciężar gatunkowy niż wskazane wcześniej. Można do nich zaliczyć pomyłki w odpowiedziach na poszczególne pytania, czy też niewłaściwą ich redakcję, rzutującą na niepoprawną odpowied $z^{69}$. Jest to o tyle niepokojące, że student dążący do weryfikacji zdobytej wiedzy, zamiast ją sprawdzić, został zmuszony do dywagowania, czy jego tok myślenia jest niepoprawny, czy też Autorka pytań dopuściła się uchybień. Podniesiony zarzut nie jest może aż tak znaczący, ale na tle całości zbioru zdaje się potwierdzać jego wątłą przydatność dla celów dydaktycznych. Zasadne jest także wspomnienie o pytaniach, które są zbyt szczegółowe i przez to, zamiast sprawdzać rozumienie jakiejś instytucji prawnej, odwołują się do pamięciowego odtworzenia wiedzy ${ }^{70}$.

Ponadto trzeba wskazać, że Autorka zrezygnowała z odesłania do podręczników prawa rzymskiego (a także fontes iuris), co nie jest praktyką spotykaną w tego typu wyborach pytań czy kazusów ${ }^{71}$. Wydaje się, że jest to zabieg niewłaściwy, gdyż zamieszczenie bibliografii prac nie tylko odsyłałoby czytelnika do pogłębienia wiedzy z prawa rzymskiego, ale także wskazywałoby, z jakich książek korzystano podczas redakcji poszczególnych pytań. Uważna lektura klucza odpowiedzi zdradza prace, do których sięgnęła Autorka - tj. podręcznik K. Kolańczyka ${ }^{72}$ oraz słownik W. Litewskiego ${ }^{73}$. Wydaje

68 R. Taubenschlag, op. cit., s. 99-101; W. Osuchowski, op. cit., s. 163-165; L. Wenger, op. cit., s. $222-$ -228; M. Kaser, K. Hackl, op. cit., s. 131 i nast.; K. Kolańczyk, op. cit., s. 123-124; A. Guraino, op. cit., s. 182; C. Sanfilippo, op. cit., s. 120; W. Litewski, op. cit., s. 383-385; A. Dębiński, op. cit., s. 104; M. Kuryłowicz, A. Wiliński, op. cit., s. 67; W. Wołodkiewicz, M. Zabłocka, op. cit., s. 297-298.

69 Por. pytanie 275 (odp. na s. 233), 586 (odp. na s. 262), 663 (odp. na s. 268).

70 Zob. pytania $100,522,803,829$.

71 T. Palmirski, R. Pabis, J. Reszczyński, op. cit., s. 255-256; A. Kacprzak, J. Krzynówek, op. cit., s. XIX-XXI; Prawo rzymskie..., s. 269-270; J. Misztal-Konecka, M. Wójcik, op. cit., s. 191-192. Można przy okazji wskazać inne użyteczne wybory tekstów źródłowych, gdzie zainteresowany czytelnik znajdzie odesłanie do literatury - A. M. Wasyl, T. Palmirski, Responsa prudentium. Wybór tekstów źródłowych zawierających poglądy rzymskiej jurysprudencji, Kraków 2000, s. 371-372.

72 W. Litewski, Stownik encyklopedyczny prawa rzymskiego, Kraków 1998. Praca ta wymieniana jest w kilku miejscach w kluczu odpowiedzi - s. 199, 215, 220, 222-223.

73 K. Kolańczyk, Prawo rzymskie, Warszawa 1997 - z tego wydania korzystano, a nawiązuje się do niego przy udzielaniu odpowiedzi na pytanie 448 (s. 249). 
się, że powołanie się wyłącznie na wskazane pozycje nie spełnia minimum, jakiego można by oczekiwać po wyborze pytań testowych. Uwaga ta nie może być postrzegana jako samodzielnie dyskredytująca wartość recenzowanej pracy, a jedynie dopełnia negatywny obraz, jaki wyłania się z lektury tego zbioru.

Konkludując, należy stwierdzić, że cel, jaki założyła sobie Autorka na wstępie pracy, nie został osiągnięty. Wskazane usterki zamiast sprzyjać powtórce wiedzy, dodatkowo ją gmatwają. Błędne odpowiedzi, nieprecyzyjne, a także szczegółowe pytania o kwestie drugorzędne zamiast zachęcać do dalszej lektury i szukania odpowiedzi, odnoszą skutek zupełnie przeciwny - zniechęcają do utrwalania wiedzy. Tym samym wydaje się, że student, który odstąpi od rozwiązywania przedmiotowego zbioru, niewiele straci, a nawet zyska, bowiem uniknie wielu dylematów, jakie wynikną przy odpowiedziach na poszczególne pytania. Negatywnego odbioru całego wyboru pytań nie są $\mathrm{w}$ stanie zniwelować nawet te liczne poprawne i ciekawie zredagowane. Skala i powaga podniesionych błędów merytorycznych jest na tyle istotna, że nie mogą zostać one zbilansowane pozytywną percepcją pozostałych pytań.

Dziwi jeszcze jedna kwestia - niezdecydowania się wydawnictwa na fachową recenzję dokonaną przez kompetentnego badacza prawa rzymskiego. Wydaje się, że jest to niezbędne w przypadku, gdy wybór kazusów bądź pytań testowych jest przygotowywany przez młodego pracownika naukowego. Skorzystanie z opinii uznanego eksperta pozwoliłoby uniknąć wielu błędów i wypaczeń, do jakich doszło w przedmiotowej pracy.

Wszystkie uwagi podniesione powyżej prowadzą do ogólnej konkluzji, w myśl której praca D. Mróz nie zasługuje na rekomendację do korzystania z niej. Odstępując od rozwiązywania pytań, studenci unikną wielu niepotrzebnych dylematów i rozczarowań. Jako postulat de lege ferenda można zasugerować wyeliminowanie wskazanych mankamentów pracy i po opatrzeniu jej stosowną recenzją romanisty, ponownie złożyć do druku. Zabieg ten nie tylko uwiarygodni merytoryczną zawartość zbioru, ale sprawi też, że z czystym sumieniem będzie można polecać studentom wybór pytań testowych autorstwa Dominiki Mróz. 